\title{
Implementasi Politik Hukum Kaitannya dengan Fungsi Pemerintah Dalam Penetapan Upah Pekerja dalam Perspektif Asas Keadilan dan Asas Kepastian Hukum
}

\author{
Wiwi Yuhaeni \\ Fakultas Hukum, Universitas Pasundan \\ E-mail:wiwi.yuhaeni@unpas.ac.id
}

\begin{abstract}
Wage system need to be developed by taking into account the balance between work performance or productivity, workers needs and company capabilities. The formulations of the problem, how the implementation of the legal politics is related to the functions of government in the aplication of workers wages in the perspective of the principle of justice and the principle of justice and the principke of legal certainty.Research methodes using normative judicial methods and analytical descriptive approaches and analyzed qualitatively. The conclusion is the based on Law Number 13 of 2003 Concerning Emploiment, that income that meets a decent income is intended for workers and their families, whereas in The Minister of Labor and Transmigration Regulation Number - PER-13/MEN/VII/ 2012, the need for a decent living is only intended only for workers or single workers.
\end{abstract}

\begin{abstract}
Abstrak. Sistem pengupahan perlu dikembangkan dengan memperhatikan keseimbangan antara prestasi atau produktivitas kerja, kebutuhan pekerja dan kemampuan perusahaan. Perumusan masalahnya adalah bagaimanakah implementasi politik hukum kaitannya dengan fungsi pemerintah dalam penetapan upah upah pekerja dalam perspektif asas keadilan dan asas kepastian hukum.Metode penelitian menggunakan metode yuridis normatif dan pendekatan secara deskriptif analitis dan dianalisis secara kualitatif. Kesimpulannya berdasarkan UU No. 13 Th 2003 tentang Ketenagakerjaan, bahwa penghasilan yang memenuhi penghasilan yang layak ditujukan bagi pekerja/buruh dan keluarganya, sedangkan dalam Permenakertrans No.PER13/MEN/VII/2012, kebutuhan hidup layak hanya ditujukan bagi pekerja/buruh saja atau pekerja status lajang saja. Sekarang berlaku PP No.78 Th 2015 tentang Pengupahan, dalam PP ini yang dikatakan hidup layak sama halnya dengan UU No.13 Th 2003 tentang Ketenagakerjaan. Jadi PP ini bukan semakin baik malah memperparah/ memprihatinkan bagi pekerja seluruh Indonesia.
\end{abstract}

Kata kunci : politik hukum, upah pekerja.

\section{A. PENDAHULUAN}

\section{Latar Belakang Penelitian}

Upah merupakan hak pekerja/buruh yang seharusnya dapat memenuhi kebutuhan mereka dan keluarganya. Sistem pengupahan perlu dikembangkan dengan memperhatikan keseimbangan antara prestasi atau produktivitas kerja, kebutuhan pekerja dan kemampuan perusahaan. Dalam menghadapi era ekonomi yang semakin maju dan berkembang dimana kebutuhan setiap orang semakin bertambah. Indonesia sebagai salah satu negara yang berkembang setidaknya harus menyiapkan upaya-upaya dini dalam mengatisipasi era tersebut.

Salah satu upaya yang harus dilakukan adalah perlunya kajian kritis atas penghidupan pekerja/buruh yang selama ini masih menjadi persoalan ketenagakerjaan di Indonesia, khususnya pemenuhan upah pekerja yang dirasakan masih rendah. Pemenuhan terhadap kesejahtaraan pekerja sebenarnya telah mendapat perhatian dari pemerintah, sebagaimana diamanatkan dalam GBHN :

"Kebijaksaan pengupahan dan penggajian didasarkan pada kebutuhan hidup, mengmbangkan diri dan keluarga tenaga kerja dalam 


\begin{abstract}
sistem upah yang tidak menimbulkan kesenjangan sosial dengan mempertimbangkan prestasi dan nilai kemanusiaan yang menimbulkan harga diri". ${ }^{1}$
\end{abstract}

Ketetapan MPR tersebut merupakan implementasi politik hukum dan tanggung jawab pemerintah dalam memberikan jaminan kondisi pengupahan yang sehat sehingga kepentingan pekerja dapat terlindungi.

Seiring dengan pertumbuhan ekonomi Indonesia yang tidak stabil, merupakan salah satu faktor yang mempengaruhi upah pekerja. Karena tidak stabilnya perekonomian tentu akan mempengaruhi harga-harga kebutuhan pokok bagi masyarakat dan khususnya bagi pekerja untuk memenuhi kebutuhan hidup dirinya beserta keluarganya . Begitu juga untuk para pengusaha berpengaruh pada biaya produksi perusahaan dan akan mempengaruhi pula pada kelangsungan perusahaan.

$$
\text { Dalam penentuan Upah }
$$

Minimum pada saat ini harus mengacu pada kebutuhan hidup layak, tetapi dalam pengaturannya terdapat perbedaan yang mendasar yang sangat mempengaruhi pengupahan di Indonesia, yaitu pada Undang-Undang Nomor 13 Tahun 2003 tentang Ketenagakerjaan, dinyatakan bahwa dalam definisi kebutuhan hidup layak ditujukan bagi pekerja dan keluarganya sedangkan dalam peraturan pelaksanaannya yaitu Permenakertrans No.Per-13/Men/VII/2012 tentang Komponen dan Pelaksaan Tahapan Pencapaian Kebutuhan Hidup Layak, ditujukan hanya bagi pekerja lajang saja tanpa adanya keluarga. Hal ini sangat

${ }^{1}$ Ketetapan MPR RI No.II/MPR/1993 tentang GBHN berpengaruh terhadap besaran upah yang akan diterima oleh setiap pekerja dan upah yang harus dikeluarkan oleh pengusaha dan akan berpengaruh terhadap jaminan sosial tenaga kerja ataupun pesangon dan lainnya. Sekarang berlaku PP No.78 Tahun 2015 tentang Pengupahan, dimana dalam Pasal 4 ayat (1), disebutkan bahwa penghasilan (kebutuhan) yang layak disamping untuk dirinya juga untuk keluarganya. Isi dari pasal tersebut sama halnya dengan yang termuat di dalam UU No.13 Th 2003 tetang Ketenagakerjaan yaitu perolehan upah disamping untuk dirinya sendiri juga untuk keluarganya, yang mengakibatkan ketidak adilan dan kurang adanya kepastian hukum bagi pekerja/buruh di wilayah Indonesia.

Hal ini merupakan tantangan besar bagi Dewan Pengupahan dalam memberikan saran dan pertimbangan bagi penetapan upah minimum yang berdasarkan pada kebutuhan hidup layak, karena setiap pihak yang berkaitan dengan pengupahan ini harus mempunyai kesamaan pandangan terlebih dahulu untuk menetapkan upah minimum tersebut agar dapat menghasilkan kebijakan yang didasarkan pada data-data yang objektif dan pertimbangan yang matang, sehingga tidak akan menjadi masalah dikemudian hari.

Dengan latar belakang di atas tadi maka penulis tertarik untuk mengadakan penelitian dengan judul : "Implementasi Politik Hukum Kaitannya Dengan Fungsi Pemerintah Dalam Penetapan Upah Pekerja Dalam Perspektif Asas Keadilan dan Asas Kepastian Hukum".

Indetifikasi Masalah

Sebagaimana latar belakang 
yang diurakan di atas, maka perumusan masalahnya adalah bagaimanakah Implementasi Politik Hukum Kaitannya Dengan Fungsi Pemerintah Dalam Penetapan Upah Pekerja Dalam Perspektif Asas Keadilan dan Asas Kepastian Hukum.

\section{B. METODE PENELITIAN}

Penelitian ini menggunakan metode yuridis normatif, dan pendekatan secara deskriptif analitis, serta dianalisis secara kualitatif, dengan mengkaji hukum yang berlaku di Indonesia melalui peraturan perundangundangan yang terkait dengan masalah upah pekerja dalam perspektif asas keadilan dan asas perlindungan hukum. Data yang diperoleh berupa data primer dan data sekunder yang akan dianalisis menggunakan metode yuridis kualitatif.

Sehubungan penelitian ini menggunakan metode yuridis normatif, maka data yang diperoleh berupa data yang didapat dari penelitian kepustakaan (library research) berupa data sekunder, dengan mengkaji bahanbahan hukum, yaitu bahan hukum primer, bahan hukum yang mengikat berupa peraturan perundang-undangan yang memiliki kaitan dengan penelitian yang dilakukan antara lain UndangUndang Nomor 13 Tahun 2003 tentang Ketenagakerjaan. Bahan hukum sekunder pada dasarnya digunakan untuk memberikan penjelasan terhadap bahan hukum primer yaitu teori-teori yang diperoleh dari literatur hukum, hasil penelitian, artikel ilmiah, maupun website yang terkait dengan penelitian dan bahan hukum tersier merupakan bahan hukum yang memberikan penjelasan dan petunjuk terhadap bahan hukum primer dan bahan hukum

2 Moh.Mahfud MD, diambil dari bahan perkuliahan Politik Hukum, dosen : Prof.Dr.Mashudi,S.H., M.H, Pascasarjana- sekunder, biasanya berupa kamus, ensiklopedi dan lain-lain.

\section{Tinjauan Teori}

\section{A. Politik Hukum dan Fungsi Pemerintah Dalam Ketenagakerjaan.}

Pemberdayaan dan pendayagunaan tenaga kerja merupakan suatu kegiatan yang terpadu untuk dapat memberikan kesempatan kerja seluas-luasnya bagi tenaga kerja Indonesia. Melalui pemberdayaan dan pendayagunaan ini tenaga kerja Indonesia dapat berpartisipasi secara optimal dalam Pembangunan Nasional, namun dengan tetap menjunjung nilai-nilai kemanusiaannya.

Nilai-nilai kemanusiaan tersebut seperti perlidungan atas hak-hak dalam hubungan kerja,perlindungan atas hak-hak dasar pekerja/buruh untuk berunding dengan pengusaha dan mogok kerja, perlindungan keselamatan dan kesehatan kerja, perlindungan khusus bagi pekerja/buruh perempuan, anak, dan penyandang cacat, perlindungan tentang upah, kesejahteraan, dan jaminan sosial tenaga kerja (Jamsostek sekarang BPJS Ketenagakerjaan) serta perlindungan atas hak pemutusan hubungan kerja.

Perlindungan kerja tersebut merupakan salah satu implementasi politik hukum pemerintah. Politik hukum adalah kebijaksanaan hukum (legal policy) yang akan atau yang telah dilaksanakan secara nasional oleh pemerintah. ${ }^{2}$ Di Indonesia politik hukum tersebut kaitannya dengan fungsi/tugas dari bidang ketenagakerjaan adalah pemerintah

UNPAS, Program Doktor Ilmu Hukum, Sabtu,25 November 2017. 
dalam hal ini pemerintah dalam arti sempit yaitu Presiden (eksekutif) bersama-sama dengan Dewan Perwakilan Rakyat, kemudian Gubernur bersama-sama dengan Dewan Perwakilan Daerah Provinsi dan Bupati atau Walikota dengan Dewan Perwakilan Daerah Kabupaten atau Kota. Fungsi atau tugas dari pemerintah tersebut merupakan salah satu pelaksanaan kesejahteraan untuk warga negaranya khususnya bidang Ketenagakerjaan.

\section{B. Hukum Ketenagakerjaan, Pekerja, Upah dan Penghidupan Yang Layak}

Pengertian hukum ketenagakerjaan, dahulu disebut hukum perburuhan atau dalam bahasa Belanda disebut arbeidrechts. Tidak satupun batasan pengertian itu dapat memuaskan karena masing-masing ahli hukum memiliki sudut pandang yang berbeda, akibatnya pengertian yang dibuatnya tentu berbeda antara pendapat yang satu dengan pendapat yang lainnya. ${ }^{3}$ Pendapat ahli hukum mengenai pengertian hukum ketenagakerjaan diantaranya :

1. Molenaar, ${ }^{4}$ menyebutkan bahwa :

"Hukum Perburuhan adalah bagian hukum yang berlaku, yang pada pokoknya mengatur hubungan antara tenaga kerja dan pengusaha,

${ }^{3}$ Abdul Khakim, Pengantar

Ketenagakerjaan Indonesia Berdasarkan Undang-Undang Nomor 13 Tahun 2003 (edisi revisi),PT.Citra Aditya

Bakti,Bandung,2007,hlm.4.

${ }^{4}$ Molennar dalam Zainal Asikin,dkk, Dasar-Dasar Hukum Perburuhan, PT.Raja Grafindo Persada, Jakarta, 1993, hlm.2 antara tenaga kerja

dengan tenaga kerja serta antara tenaga kerja

dengan penguasa (pemerintah)".

2. Mok, ${ }^{5}$ menyebutkan bahwa :

"Hukum Perburuhan adalah hukum yang berkenaan dengan pekerjaan yang dilakukan di bawah pimpinan orang lain dengan keadaan penghidupan yang langsung bergandengan dengan pekerjaan itu".

3. Soepomo, ${ }^{6}$ menyebutkan bahwa :

"Hukum Perburuhan
adalah himpunan
peraturan-peraturan
baik tertulis maupun
tidak tertulis, yang
berkenaan dengan
kejadian di mana
seseorang bekerja pada
orang lain dengan
menerima upah".

Abdul Khakim, berpendapat bahwa istilah tenaga kerja mengandung pengertian yang amat luas dan berpendapat bahwa istilah hukum ketenagakerjaan lebih tepat dibanding dengan istilah hukum perburuhan. Hal ini juga sejalan dengan penamaan Undang-Undang Nomor 13 Tahun 2003 tentang Ketenagakerjaan, bukan Undang-

${ }^{5}$ Mok dalam Kansil,C.S.T, Pengantar Hukum dan Tata Hukum Indonesia, Balai Pustaka, Jakarta, 1989, hlm.311.

${ }^{6}$ Soepomo dalam Sendjun H.Manulang, Pokok-Pokok Hukum Ketenagakerjaan di Indonesia, Rineka Cipta, Jakarta, 1995, hlm.2. 
Undang Perburuhan. ${ }^{7}$ Menurut Pasal 1 butir 3 Undang-Undang Nomor 13 Tahun 2003 tentang Ketenagakerjaan, disebutkan bahwa : "Pekerja/buruh adalah setiap orang yang bekerja dengan menerima upah atau imbalan lain".

Pengertian Upah sebagaimana tercantum dalam pasal 1 butir 30 Undang-Undang Nomor 13 Tahun 2003 tentang Ketenagakerjaan, adalah :

"Hak pekerja/buruh yang diterima dan dinyatakan dalam bentuk uang sebagai imbalan dari pengusaha atau pemberi kerja kepada pekerja/buruh yang ditetapkan dan dibayarkan menurut suatu perjanjian kerja, kesepakatan, atau peraturan perundangundangan, termasuk tunjangan bagi pekerja/ buruh dan keluarganya atas suatu pekerjaan dan/atau jasa yang telah atau akan dilakukan". Dalam Penjelasan Pasal 88 ayat (1) Undang-Undang Nomor 13 Tahun 2003 tentang Ketenagakerjaan, dijelaskan bahwa : "Penghasilan yang memenuhi penghidupan yang layak adalah jumlah penerimaan atau pendapatan pekerja/buruh dan keluarganya secara wajar yang meliputi makanan, minuman, sandang, perumahan, pendidikan, rekreasi, dan jaminan hari tua".

Pasal 1 ayat (1) Peraturan Menteri Tenaga Kerja dan Transmigrasi No.PER-

${ }^{7}$ Abdul Khakim, Pengantar Hukum Ketenagakerjaan...Op.Cit.,hlm.5

${ }^{8}$ Sudikno Mertokusumo dan A.Pitlo, Bab-Bab Tentang Penemuan Hukum, Citra Aditya Bakti, Bandung, 1993,hlm.1.
13/MEN/VII/2012 tentang

Komponen dan Pelaksanaan

Tahapan Pencapaian Kebutuhan Hidup Layak, dijelaskan pengertian kebutuhan hidup layak yaitu :

"Standar kebutuhan yang harus dipenuhi oleh seorang pekerja/buruh lajang untuk dapat hidup layak baik secara fisik, non fisik dan sosial untuk kebutuhan 1 (satu) bulan".

Menurut PP No.78 Th 2015 tentang Pengupahan, dimana dalam Pasal 4 ayat (1), disebutkan bahwa : "Penghasilan (kebutuhan) yang layak merupakan jumlah penerimaan atau pendapatan pekerja/buruh dari hasilpekerjaannya disamping untuk dirinya juga untuk keluarganya".

C. Asas Keadilan dan Asas Kepastian Hukum Dalam Upah Pekerja

Kebijakan pengupahan di Indonesia harus memenuhi asas keadilan dan asas kepastian hukum yang diperlukan bagi negara hukum. Sudikno Mertokusumo dan A.Pitlo : 8

"Dalam suatu negara hukum harus memberi jaminan adanya penegakan hukum dan tercapainya tujuan hukum dan dalam penegakan hukum ada tiga unsur yang selalu harus mendapat perhatian yaitu : keadilan, kemanfaatan atau hasil guna, dan kepastian hukum".

Begitupula yang dikemukakan oleh Moctar Kusumaatmadja : ${ }^{9}$

${ }^{9}$ Mochtar Kusumaatmadja, Fungsi dan Perkembangan Hukum Dalam Pembangunan Nasional, Bina Cipta, Bandung, hlm.2. 
"Tujuan pokok dari hukum ketertiban. Kepatuhan akan ketertiban ini, syarat pokok untuk masyarakat yang teratur. Tujuan hukum lainnya adalah tercapainya keadilan. Untuk mencapai ketertiban dibutuhkan kepastian hukum dalam pergaulan antar manusia dalam masyarakat”.

Pendapat Romli Atmasasmita : ${ }^{10}$

"Tujuan hukum integratif yaitu adanya kedamaian dalam keseimbangan antara kepastian hukum, kemanfaatan dan keadilan ( dalam satu nafas )".

Hukum harus dilaksanakan dan ditegakan. Setiap orang mengharapkan ditetapkannya hukum dalam hal terjadinya peristiwa konkrit. Itulah yang diinginkan oleh kepastian hukum. Kepastian hukum merupakan perlindungan terhadap tindakan sewenang-wenang, yang berarti seseorang akan dapat memperoleh sesuatu yang diharapkan dalam keadaan tertentu. Masyarakat mengharapkan adanya kepastian, karena dengan adanya kepastian hukum masyarakat akan lebih tertib. Hukum bertugas menciptakan kepastian hukum, dengan itu akan tercapainya tujuan hukum yang lain, yaitu ketertiban. Penegakan hukum harus memberi manfaat pada masyarakat, disamping bertujuan menciptakan keadilan. $^{11}$ Menurut

${ }^{10}$ Romli Atmasasmita, diambil dari bahan perkuliahan Politik Hukum, dosen : Prof.Dr.H.Mashudi, S.H.,M.H, Pascasarjana UNPAS, Program Doktor Ilmu Hukum, Sabtu, 25 November 2017.

${ }^{11}$ Sudikno Mertokusumo dan A.Pitlo, Bab-Bab Tentang...Op.Cit.,hlm.2.

12 Satjipto Rahardjo (Hukum Progresif, Teori Satjipto Rahardjo) dalam Bernard
Satjipto Rahardjo, ${ }^{12}$ pemikiran hukum perlu kembali pada filosofi dasarnya, yaitu hukum untuk manusia. Dengan filosofi tersebut, maka manusia menjadi penentu dan titik orientasi hukum. Hukum bertugas melayani manusia, bukan sebaliknya. Oleh karena itu, hukum itu bukan merupakan institusi yang lepas dari kepentingan manusia. Mutu hukum, ditentukan oleh kemampuannya untuk mengabdi pada kesejahteraan manusia. Ini menyebabkan hukum progresif "idiologi" : hukum yang prokeadilan dan hukum yang prorakyat.

\section{PEMBAHASAN}

Sebagaimana perumusan masalah yang tercantum dalam identifikasi masalah di atas, maka pembahasannya adalah sebagai berikut :

Bagaimanakah Implementasi Politik Hukum Kaitannya Dengan Fungsi Pemerintah Dalam penetapan Upah Pekerja Dalam Perspektif Asas Keadilan dan Asas Kepastian Hukum.

Mengkaji dari uraian di atas mulai dari latar belakang, dan identifikasi masalah dengan mengunakan metode yuridis normatif, maka analisis penulis adalah bahwa, berdasarkan UndangUndang Nomor 13 Tahun 2003 tentang Ketenagakerjaan, bahwa penghasilan yang memenuhi

L.Tanya ,dkk, Teori Hukum, Strategi Tertib Manusia Lintas Ruang dan Generasi, Genta Publishing, Yogyakarta, 2010, hlm.20.Lihat juga Suteki, Rekam Jejak Pemikiran Hukum Progresif Satjipto Rahardjo, dalam buku : Satjipto Rahardjo dan Hukum Progresif Unrgensi dan Kritik, Epistema Institut-HuMaJakarta, 2011, hlm.34. 
penghidupan yang layak ditujukan bagi pekerja/buruh dan keluarganya. Sedangkan dalam Peraturan Menteri Tenaga Kerja dan Transmigrasi No.PER13/MEN/VII/2012, kebutuhan hidup layak hanya ditujukan bagi pekerja/buruh saja atau pekerja status lajang saja.Sehingga menurut Permenakertrans ini ada kemajuan karena dimana kehidupan layak ini hanya untuk pekerja itu sendiri tetapi kenyataan dalam praktik perusahaan-perusahaan mengacu terhadap ketentuan hidup layak berdasarkan UU No.13 Tahun 2003. Tidak heran kalau terjadi ketidak puasan dari para pekerja/buruh untuk demo karena meminta tuntutan/hak sebagai pekerja. Sekarang berlaku PP No.78 Th 2015 tentang Pengupahan, dalam PP ini yang dikatakan hidup layak sama halnya dengan UU No.13 Th 2003 tentang Ketenagakerjaan. Jadi PP ini bukan semakin baik malah memperparah/memprihatinkan bagi para buruh/pekerja seluruh Indonesia.

Dari uraian di atas tadi kalau dikaitkan dengan asas keadilan dan asas kepastian hukum tentunya pengaturan Upah Minimum Kabupaten/Kota perlu adanya perubahan sebagai politik hukum dari pemerintah dan kembali lagi pengaturan "kehidupan yang layak" seperti yang diatur dalam Permenakertrans dan dilaksanakan dalam praktik. Sebagaiman kita ketahui negara Indonesia adalah "negara hukum", yang dikemukakan oleh Sudikno Mertokusumo dan

\footnotetext{
${ }^{13}$ Sudikno Mertokusumo, Bab-Bab

Tentang....Loc.Cit.

${ }^{14}$ Mochtar Kusumaatmadja, Fungsi dan...Loc.Cit.
}

A.Pitlo, ${ }^{13}$ tujuan hukum dalam penegakan hukum ada tiga unsur yaitu : keadilan, kemanfaatan atau hasil guna dan kepastian hukum. Menurut Mochtar Kusumaatmadja, ${ }^{14}$ bahwa tujuan hukum disamping adanya ketertiban yaitu adanya keadilan. Pendapat Romli Atamasasmita, ${ }^{15}$ bahwa tujuan hukum integratif yaitu adanya kedamian dalam keseimbangan antara kepastian hukum, kemanfaatan dan keadilan ( dalam satu nafas). Pendapat Satjipto Rahardjo, ${ }^{16}$ secara singkat, hukum bertugas melayani manusia, mutu hukum ditentukan oleh kemampuannya untuk mengabdi pada kesejahteraan manusia.

\section{KESIMPULAN}

Berdasarkan ketentuan tentang Upah Minimum Kota/Kabupaten yang merujuk dalam Upah Minimum Provinsi, pengaturan tentang "Kehidupan Yang Layak" bagi pekerja/buruh seluruh Indonesia, perlu adanya perubahan dan sebaiknya seperti halnya dalam isi Peraturan Menteri Tenaga Kerja dan Transmigrasi Nomor PER13/MEN/VII/2012 tentang Komponen dan Pelaksanaan Tahapan Pencapaian Kebutuhan Hidup Layak, dijelaskan bahwa kebutuhan hidup layak hanya ditujukan bagi pekerja/buruh saja atau pekerja status lajang. Sedangkan hidup layak yang diatur dalam Peraturan Pemerintah Nomor 78 Tahun 2015 tentang Pengupahan, kebutuhan hidup layak disamping untuk pekerja juga dipergunakan juga untuk keluarganya sama seperti

\footnotetext{
${ }^{15}$ Romli Atmasasmita...Loc.Cit.

${ }^{16}$ Satjipto Rahardjo,..Loc.Cit.
} 
halnya yang diatur dalam UndangUndang Nomor 13 Tahun 2003 tentang Ketenagakerjaan. Jadi isi dari PP tersebut adanya kemunduran bukan perbaikan, yang bertentangan dengan asas keadilan dan asas kepastian hukum bagi upah pekerja/buruh seluruh Indonesia.

\section{DAFTAR PUSTAKA}

\section{Buku-buku :}

Abdul Khakim, Pengantar Ketenagakerjaan Indonesia Berdasarkan Undang-Undang Nomor 13 (edisi revisi) PT.Citra Aditya Bakti, Bandung, 2007.

Bernard L.Tanya, dkk, Teori Hukum, Strategi Tertib Manusia Lintas Ruang dan

Generasi, Genta Publishing, Yogyakarta, 2010.

Kansil, C.S.T., Pengantar Hukum dan Tata Hukum Indonesia, Balai Pustaka,Jakarta, 1989.

Mochtar Kusumaatmadja, Fungsi dan Perkembangan Hukum Dalam Pembangunan

Nasional, Bina Cipta, Bandung.

Sendjun H.Manulang, Pokok-Pokok Hukum Ketenagakerjaan di Indonesia,Rineka Cipta, Jakarta, 1995.

Sudikno Mertokusumo dan A.Pitlo, Bab-Bab Tentang Penemuan Hukum, Citra Aditya Bakti, Bandung, 1993.

Zainal Asikin,dkk, Dasar-Dasar Hukum Perburuhan, PT.Raja Grafindo Persada, Jakarta, 1993.

\section{Peraturan Perundang-Undangan :}

Undang-Undang Dasar 1945.
Undang-Undang Nomor 13 Tahun 2003 tentang Ketenagakerjaan.

Peraturan Pemerintah Nomor 78 Tahun 2015 tentang Pengupahan.

Peraturan Menteri Tenaga Kerja dan Transmigrasi Nomor PER13/MEN/VII/2012

Tentang Komponen dan Pelaksanaan Tahapan Pencapain Kebutuhan Hidup

Layak.

\section{Sumber Lainnya :}

Bahan-bahan Perkuliahan Politik Hukum, dosen : Prof .Dr.H.Mashudi, S.H, M.H, Pascasarjana-UNPAS, Program Doktor Ilmu Hukum, Sabtu, 25 November

2017. 